\title{
Relationship between School Principals' Distributed Leadership Style and Teachers' Organizational Commitment in Public Secondary Schools in Anambra State, Nigeria
}

\author{
V.C. Mbonu and I.M. Azuji
}

\section{ABSTRACT}

This study investigated the relationship between school principals' distributed leadership style and teachers ${ }^{\text {ee }}$ organizational commitment in public secondary schools in Anambra state, Nigeria. Three research questions guided the study while one null hypothesis was tested at 0.05 level of significance. Correlational research design was used in conducting the study. The sample comprised 1,105 teachers. Two research instruments, namely; Leadership Density Inventory (LDI) (Smith, Ross, and Robichaux, 2004) and Organizational Commitment Questionnaire (OCQ) were used for data collection. The reliability coefficient value the instruments is as follows; $r=0.85$ for LDI and 0.73 for CDQ. Copies of the instruments were distributed by the researchers through direct delivery to the respondents. Pearson Product-Moment Correlation Coefficient was used to answer the research question, while t-test of significance of relationship was used in testing of the null hypothesis. The findings of the study showed, among others, that there is a significant low positive relationship between the distributed leadership style of Secondary school principals in Anambra State and teacher's commitment to the organization. Based on the findings of the study, it is recommended that increased knowledge of the relationship between distributed leadership and teacher commitment should be applied by the school management commission in order to equip principals and other school leaders.

Keywords: principals' leadership style, organizational commitment, distributed leadership, public schools.

\section{INTRODUCTION}

Globally, organisations are moving towards a more representative organisational leadership approach. As a result, the assumption is that school administrators must adjust to the transition in workplace governance and meet the abilities of the faculty and employees of the company for employees of organisations such as school to have a higher control and a broader reach in the organisation. The concepts of shared leadership could provide a vital tool in addressing the challenges facing school leaders in optimising the contributions of faculty, particularly in the areas of employee commitment to organisations.

According to Douglas (2010), organisational commitment describes the recognition and participation of a person in a specific job or organisation. A deep belief in the goals and ideals of the company or organisation, acceptance of the job and a commitment to work for the organization's improvement, and a strong will to continue with the organisation can characterise it. However, in the sense of this
Published Online: January 07, 2021

ISSN: $2736-4534$

DOI : $10.24018 /$ ejedu.2021.2.1.19

\section{V.C. Mbonu}

Department of Management and Policy, Nnamdi Azikiwe University, Awka, Nigeria..

(e-mail: mbonuvictoria73@gmail.com)

\section{I.M. Azuji*}

Department of Guidance and Counselling, Nnamdi Azikiwe University, Awka, Nigeria. (e-mail: ifeanyichukwua@gmail.com)

*Corresponding Author study, commitment is defined as the firm belief of a worker in and appreciation of the mission and values of his or her organisation and a desire to exercise his or her own willingness to improve the organisation.

Many factors such as the work environment, expertise, abilities, training skills, experience, availability of resources, willingness to take part in a job, improvement of the job and the overall satisfaction derived from the job may determine the commitment of a worker to the organisation. For example, in school environments, teachers who have entered the profession are more likely to persist and stay with the organisation, being confident of their career choice (Steen \& Kaffenberger, 2007; Zacharo, KMarios \& Dimitra, 2018). This suggests that employees who have chosen the profession are more likely to show positive attitudes towards their job and therefore experience a greater devotion to their job and continue through the everyday difficulties of their teaching position. Organizational commitment could be seen as an indicator of teacher effectiveness.

Singh and Billingsley (2001) found in schools, for 
example, that dedicated teachers have greater work commitment and engagement, and are less likely to leave their jobs and exhibit other withdrawal habits, such as absenteeism. Likewise, Owens and Valesky (2015) noted that organisational involvement is a vital indicator of the job performance of teachers, as commitment is important for teachers to be motivated to professionalise and undertake improvements in their practise while addressing the dynamic demands posed by these changes.

Research by Owens and Valesky (2015) has also shown that an employee organisational involvement is positively linked to the practise of organisational leadership. This is also the case in education (Aytac, 2015; Nguni, Sleegers, \& Denessen, 2006). However because of the increased complexity of the educational system, and particularly in large public secondary schools, it is likely that no person has all the expertise, skills and abilities that would allow him/her to perform all the leadership functions without distributing them among a team.

Conger and Pearce (2003) developed a post-heroic model of leadership. In this model, leadership is a group-level phenomenon in which the school team distributes leadership. While empirical research exploring distributed leadership from a descriptive perspective and examining the link with school efficiency and school advancement is still in its infancy in developing nations such as Nigeria. So in this important field, not much has been done about the essence and necessity of distributed leadership. The social background and inter-relationships as an integral part of leadership operation are, however, central to the theoretical framing (Harris, Leithwood, Day, Sammons, \& Hopkins, 2007). When trained educators are more prominently seen as leaders inclassrooms and the broader school environment, greater attention is given to effective leadership.

Studies have also explored the antecedents of teachers ${ }^{\text {ec }}$ organisational commitment and showed that teacherse organisational commitment is formed by characteristics of administrative settings, including school leadership (Ross \& Gray, 2006; Sayadi, 2016; Unterrainer, Jeppesen, Jonsson \& Weber, 2016). Leadership has played a new position in organisational branding and success systems as a way of controlling business priorities, methods, and values. Previous studies have explored leadership styles and forms and their outcome on workers' experiences and commitment (Dinc \& Aydemir, 2014; Kajisho \& Lodisso, 2020; Ning \& Zhaoyi, 2017; Naeem et al., 2019). In collaborative skills, carefully built by professional cooperation, distributed leadership could have a positive contribution to workers' commitment and performance in the organisation.

Thus it seems obvious that the relationship between school teachers, the interaction between teachers and students, the standard of procedures and the level of apprehension of their profession by teachers all have the tendency to affect the level of organisational commitment of teachers. Lower commitment produces dilemmas that both have a detrimental effect on the success of the school and could lead teachers to be less effective in their professional output or to leave the profession. As a result, less committed teachers can both create problems and cause gaps in the educational objectives of the school.

\section{A. Statement of the Problem}

In today's educational setting, school leaders face enormous challenges. Many school leaders have come to the realisation that the role of leadership alone is enormous and challenging because of the increased pressure on educators and the complexities of the education industry. In classrooms, several problems create a series of constraints vying for educational time. Successful leadership of inspired and professionally fulfilled members of staff aligns the identity and mission of the school with the experience of students. More collaborative and inclusive approach is needed for this to occur, which might improve employee morale and involvement.

It is likely that gaining a more comprehensive understanding of distributed leadership, its application to school governance, and its contributions to the devotion of teachers to the organisation would provide useful resources for school leaders and administrators. While there are academic studies in this area that have been properly channelled to answer these issues, there is a lack of empiric literature that determined the relationship between the distributed leadership style of school principals and the commitment of teachers to the organisation in Anambra State Secondary Schools. This is a gap in the literature that will be filled by this present research.

\section{B. Purpose of the Study}

The major purpose of this study is to examine the relationship between school principals' distributed leadership style and teachers ${ }^{\text {ee }}$ organizational commitment in public secondary schools in Anambra state. Specifically, the study sought to determine:

1. The perception scores of secondary school teachers based on their perception of secondary school principal's distributed leadership style in Anambra State?

2. Scores of secondary school teachers in Anambra State based on their commitment to the organisation.

3. Relationship between school principals' distributed leadership style and teachers ${ }^{\text {ee }}$ organizational commitment in public secondary schools in Anambra state.

C. Research Questions

The following research question was posed to guide the study.

1. What are the perception scores of secondary school teachers based on their perception of secondary school principal's distributed leadership style in Anambra State?

2 What are the scores of secondary school teachers in Anambra State based on their commitment to the organisation?

3 What is the relationship between school principals' distributed leadership style and teachers ${ }^{\text {ee }}$ organizational commitment in public secondary schools in Anambra state? 


\section{Hypothesis}

The following null hypothesis guided the study and was tested at 0.05 level of significance.

1. The relationship between school principals' distributed leadership style and teacherse organizational commitment in public secondary schools in Anambra state is not significant.

\section{METHOD}

\section{A. Research Design}

The study was conducted using a correlational research design. The design was used because it sought to establish the relationship that exists between variables; Principal's distributed leadership style and teachers' organisational commitment in secondary schools in Anambra State.

\section{B. Sample and Sampling Technique}

A total of number of 1,105 teachers from public secondary schools in Anambra State made up the sample for this study. Simple random sampling was used in selecting the sample for the study.

\section{Method of Data Collection}

Two research instruments were used to elicit information from the school teachers for this study. The instruments include Leadership Density Inventory (LDI)) and Organisational Commitment (OCQ). LDI was adapted from a standardised instrument Smith, Ross, and Robichaux, (2004). The revised LDI uses a 16- question survey measuring teacher perceptions of distributed leadership within the school. The survey uses a 4-point, rating scale, which provides participants with responses ranging from never (1), to always (4). Organisational Commitment Questionnaire (OCQ) is a validated instrument that contains 16 items which aimed at measuring the commitment of school teachers to the organisation.

The two instruments were all been subjected to internal consistency reliability test using Cronbach's Alpha. The outcome yielded a coefficient Alpha of is 0.85 for LDI and 0.73. OCQ. Data was collected using a two page instrument containing both the LDI and OCQ. All the participants for the study were administered the two research instruments through direct delivery approach.

\section{Method of Data Analysis}

Statistical Package for the Social Sciences (SPSS) software was used to perform the data analysis. The data collected for the research question was analysed using Pearson ProductMoment Correlation Coefficient (Pearson r), while t-test of correlation was used to test the null hypothesis.

\section{RESULTS}

In this section, the data collected from the field for this study were analysed and the summaries presented in tables and charts to highlight the findings:

Research Question 1
What are the perception scores of secondary school teachers based on their perception of secondary school principal's distributed leadership style in Anambra State?

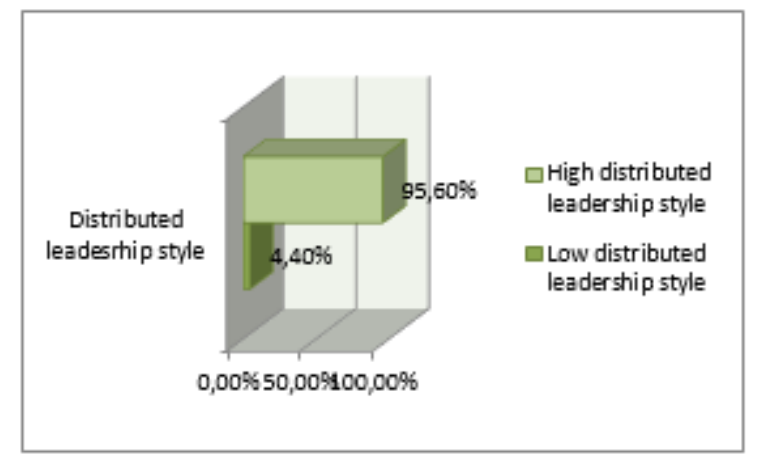

Figure 1: Distribution Scores of Secondary School Teachers Based on their perception of secondary school principal's Distributed Leadership Style in Anambra State.

Figure 1 reveals that 970 (95.6\%) of the secondary school teachers in Anambra State with the scores ranging from 24 to 40 have high distributed leadership style, while $45(4.4 \%)$ of the teachers who scored between 16 and 23.96 have low distributed leadership style.

\section{Research Question 2}

What are the distribution scores of secondary school teachers' commitment to the organisation in Anambra State?

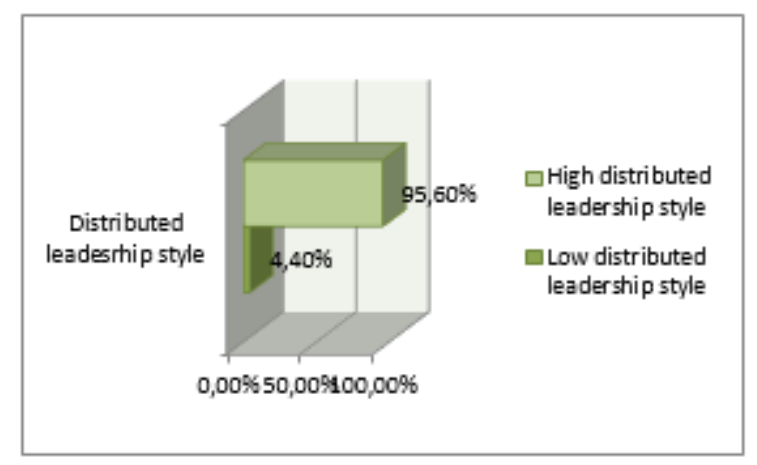

Fig. 2. Distribution Scores of Secondary School Teachers Based on their Commitment to the organisation in Anambra State

The chart above reveals that $835(82.3 \%)$ of the secondary school teachers in Anambra State with the scores ranging from 30 to 48 have more commitment to the organisation, while $180(17.7 \%)$ of the secondary school teachers who scored between 12 and 29.96 have less commitment to the organization.

\section{Research Question 3}

What is the relationship between school principals' distributed leadership style and teachers ${ }^{\text {ee }}$ organizational commitment in public secondary schools in Anambra state? 
TABLE 1: PEARSON CORRELATION ON THE RELATIONSHIP BETWEEN TEACHERS' PERCEPTION OF SCHOOL PRINCIPALS' DISTRIBUTED LEADERSHIP STYLE AND TEACHERS ${ }^{*}$ ORGANIZATIONAL COMMITMENT IN PUBLIC SECONDARY SCHOOL

\begin{tabular}{llc}
\hline Variables & N & Pearson $(\boldsymbol{r})$ Remark \\
\hline $\begin{array}{l}\text { Distributed leadership } \\
\text { style }\end{array}$ & 1,015 & \\
$\begin{array}{l}\text { Commitment to } \\
\text { organization }\end{array}$ & 1,015 & low positive \\
\hline
\end{tabular}

The table shows that there is a low positive relationship of 0.166 existing between teachers' perception of school principals' distributed leadership style and teachers ${ }^{\text {ee }}$ organizational commitment in public secondary schools in Anambra State.

\section{A. Testing the Null Hypotheses}

There will be no significant relationship between school principals' distributed leadership style and teachers ${ }^{\text {ee }}$ organizational commitment in public secondary schools in Anambra state.

TABLE 2: TEST FOR SIGNIFICANCE OF RELATIONSHIP BETWEEN SCHOOL PRINCIPALS' DISTRIBUTED LEADERSHIP STYLE AND

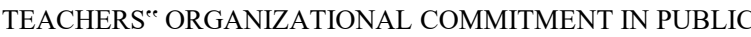
SECONDARY SCHOOL $(\mathrm{N}=1,015)$

\begin{tabular}{lllllll}
\hline Variables & $r$ & t-cal & t-crit & Df & p-value & Remark
\end{tabular}

$\begin{array}{lllllll}\text { Distributed } & 0.166 & - & 1.96 & 101 & 0.000 & \text { S } \\ \text { Leadership } & & 4.213 & & 4 & & \\ \text { Style } & & & & & & \end{array}$

Commitment

to organization

\section{S-Significant correlation at 0.05 level of significance}

Table 2 revealed that at 0.05 level of significance and $1014 \mathrm{df}$, the calculated r 0.166 has Pvalue 0.000 which is less than critical Pvalue $0.05(r=0.166, \rho<0.05)$. Therefore the null hypothesis is rejected. There is a significant relationship existing between school principals' distributed leadership style and teachers ${ }^{\text {ee }}$ organizational commitment in public secondary schools in Anambra state.

\section{DISCUSSIONS}

In this section, the findings of the study are discussed.

Distribution scores of secondary school teachers based on their perception of secondary school principal's distributed leadership style in Anambra State

The result of this research, based on teacher perceptions of the school principal's distributed leadership style, revealed that the school principals in Anambra State's public secondary school have a well-distributed leadership style. The result is an indication that, based on the opinion of teachers, school principals follow a leadership model in which leadership is shared with teachers. The Principals undertake a more democratic leadership style, using the skills and abilities of teachers to run the school. The result of the study is consistent with the findings of Kajisho and Lodisso (2020), whose research revealed that school leaders collaborated with teachers to create and improve the school's mission, vision and objectives. Such a strategy extends leadership around the school community and leverages the potential of individual principals to solve school problems.

\section{Secondary school teachers' commitment to the} organisation in secondary schools in Anambra State

The results of the study showed that most secondary school teachers in Anambra State are more committed to the organisation. The findings agree with Zacharo, KMarios and Dimitra (2018), the results of which have shown that teachers feel a deep commitment to school objectives. This means that the public secondary school teachers in Anambra state have a deep confidence in and appreciation of the objectives of the organisation.

Other factors that may have contributed to the commitment of secondary school teachers to the organisation include the sense of responsibility and autonomy that appears to be the hallmark of secondary school teachers in Anambra State. Anambra State is one state in Nigeria where secondary school teachers have autonomy. Prospects for advancement by promotion, regular wages and in-service training, among others may have contributed majorly to the observed high level of teachers' organisational commitment in schools.

\section{Relationship between School Principals' Distributed Leadership Style and Teachers' Organizational Commitment in Public Secondary School}

The results of the study showed that there is a substantial low positive relationship between the perception of teachers about the distributed leadership style of school principals and the organisational commitment of teachers in public secondary schools in Anambra State. This means that the understanding of teachers' collaborative style of leadership by school principals leads to the degree of organisational commitment of teachers in public secondary schools. The results of this study is supported by studies, such as Aytac (2015); Kajisho and Lodisso (2020) and Unterrainer, Jeppesen, Jonsson, and Weber (2016), showing that teachers who are provided with shared leadership opportunities within the school report a firm commitment to their school as an institution.

One could link the reason for this finding to the notion that the effectiveness of an education institution depends on many details; one of the most important details is the interaction of teachers and students who are permanent participants in the learning and teaching process. In this interaction, the school principal is the school manager and the school director, and the classroom director is the teacher. In this respect, the commitment of teachers to their schools as an organisation is likely to have a positive impact on the effectiveness of the school. 


\section{CONCLUSION}

The results show that there is a substantial low positive association between the distributed leadership style of the principal determined by the perception of teachers and the commitment of teachers to the school as an institution. This is an indication that school principals' leadership style that is focused on workplace performance can improve the relationship between the leader and employee within the organization.

\section{A. Implications of the Study}

The significant low, positive correlation between the distributed leadership style of principals and the commitment of teachers to their school as an institution establishes the need for principals and other school leaders to promote school governance models that efficiently share leadership with staff members.

\section{B. Recommendations}

Based on the findings of the study, it is recommended that:

1. Increased knowledge of the relationship between distributed leadership and teacher affective commitment should be applied by the school management commission in order to equip principals and other school leaders to establish governance structures more closely aligned with the strengths of teachers.

2. Supervisors of teachers in school should examine the skill sets of each teacher and determine the suitable leadership style to understand what is required to enhance their commitment at workplace.

C. Acknowledgements

The views expressed in this research are those of the authors except as acknowledged in references.

\section{REFERENCES}

T. Aytac, T. (April 2015). The relationship between teachers' perception about school managers' talent management leadership and the level of organizational commitment (online). Eurasian Journal of Educational Research, 59, pp. 165-180. Available: http://dx.doi.or/10.14689/ejer.2015.59.10.

J.A. Conger, and C.L. Pearce, "A landscape of opportunities," in Shared leadership. Reframing the hows and whys of leadership, C.L. Pearce and J.A. Conger, Eds. Thousand Oaks, CA: Sage, 2003, pp. 285-303.

M.S. Dinc, and M. Aydemir. "Ethical leadership and employee behaviours: An empirical study of mediating factors,". International Journal of Business, Governance and Ethics, vol. 9, pp. 293-312, 2014, 10.1504/ IJBGE.2014.06473

S.M. Douglas, "Organizational climate and teacher commitment" ProQuest LLC, Ed.D. , The University of Alabama, Alabama, 2010.

A. Harris, K. Leithwood, C. Day, P. Sammons, and D. Hopkins, "Distributed leadership and organizational change: Reviewing the evidence". Journal of Educational Change, vol. 8, pp. 337-347, 2007.

M. Kajisho, and S.L. Lodisso (May 2020) Distributed school leadership and teachers' organizational commitment: The case of primary schools of Hawassa City administration (online), Journal of Education and Practice, vol. 11(13), pp. 17-25. Available: https://www.iiste.org/Journals/index.php/JEP/article/download/52812/ 54566

S. Nguni, P. Sleegers, and E. Denessen ,(June 2006). Transformational and transactional leadership effects on teachers' job satisfaction, organizational commitment, and organizational citizenship behaviour in primary schools: The Tanzanian case. School Effectiveness and School Improvement, Vol. 17, pp. 145-177. Available: https://www.researchgate.net/publication/44839812
R.M. Naeem Q.D. Weng Z. Hameed and M.I. Rasheed. "Ethical leadership and work engagement: A moderated mediation model". Ethics and Behaviour, vol. 30, pp. 63-82, 2019. 10.1080/10508422.2019.1604232

N. Ning, and I. Zhaoyi. "Psychological contract breach, organizational disidentification, and employees' unethical behaviour: Organizational ethical climate as moderator", Social Behaviour and Personality: An international journal, vol. 45, 2017. 10.2224/sbp.6708.

R.G. Owens and V.C. Valesky, Organizational behaviour in education: Leadership and school reform. Boston, MA: Pearson, 2015.

J.A. Ross and P. Gray, "Transformational leadership and teacher commitment to organizational values: The mediating effects of collective teacher efficacy", School Effectiveness and School Improvement, vol. 17, pp. 179-199, 2006.

Y. Sayadi, "The effect of dimensions of transformational, transactional, and non-leadership on the job satisfaction and organizational commitment of teachers in Iran", Management in Education, vol. 30(2), pp. 57-65, 2016. https://doi.org/10.1177/0892020615625363

K. Singh, and B.S. Billingsley (April 2001). Professional support and its effects on teachers' commitment (online). The Journal of Educational Research, 91, pp. 229-239. Available:https://www.tandfonline.com/doi/abs/10.1080/0022067980 9597548

S. Steen and C.J. Kaffenberger, "Integrating academic interventions into small group counselling in elementary school", Professional School Counselling, vol. 10, pp. 516-519, 2007.

C. Unterrainer, H. Jeppesen, T. Jønsson, and W. Weber, (May 2017) Distributed Leadership Agency and Its Relationship to Individual Autonomy and Occupational Self-Efficacy:A Two Wave-Mediation Study in Denmark (online). Humanist Manag J. 2, pp. 57-81. Available:https://pure.au.dk/ws/files/120766196/Distributed_Leaders hip_Agency_and_Its_Relationship.pdf

K. Zacharo, K. Marios, and P. Dimitra, (August, 2018). Connection of teachers' organizational commitment and transformational leadership. A case study from Greece. International Journal of Learning, Teaching and Educational Research, 17(8), pp. 89-106. Available: https://www.ijlter.org/index.php/ijlter/article/view/1223 